\title{
Management of hypercalcemia of malignancy
}

\author{
Sonia Amin Thomas (Sonia Patel)* and Soo-Hwan Chung \\ Philadelphia College of Osteopathic Medicine School of Pharmacy-GA Campus, North Fulton Hospital, USA
}

\begin{abstract}
Malignancy is one of the most common causes of hypercalcemia, particularly in cancer associated with bone metastases. Hypercalcemia occurs in up to $20 \%$ to $30 \%$ of cancer patients at some time during the course of their disease. Clinical manifestations of hypercalcemia vary in calcium level in blood. Signs and symptoms of hypercalcemia occur when the serum calcium level rises above those ranges. Fluids are first-line treatment with hypercalcemia followed by bisphosphanates if the calcium is high and the patient is experiencing symptoms. Various other medications are used as second-line agents in hypercalcemia of malignancy.
\end{abstract}

\section{Introduction}

Hypercalcemia is defined as a condition in which the serum calcium level is above normal level $(>10.5 \mathrm{mg} / \mathrm{dL}$ or ionized $\mathrm{Ca}$ level $>5.6 \mathrm{mg} / \mathrm{dL}$ ). The consequences of abnormal serum calcium level can range from asymptomatic to life-threatening. In addition, excessively high serum calcium level causes clinical manifestations that affect the neuromuscular, gastrointestinal, renal, skeletal, and cardiovascular systems [1,2]. Malignancy is one of the most common causes of hypercalcemia, particularly in cancer associated with bone metastases. Since some tumor cells can resorb or destroy bone directly, hypercalcemia develops more rapidly and more aggressively than other causes of hypercalcemia, along with classic symptoms of dehydration, anorexia, nausea/vomiting, constipation, and polyuria. In multiple myeloma, for example, malignant myeloma cells secrete a cytokine (IL-6 receptor) that activate osteoclasts in vicinity of the myeloma cells leading to bone resorption. Hypercalcemia associated with malignancy is a common complication of some types of cancer, including squamous cell carcinomas, multiple myeloma, T-cell lymphoma, and breast carcinoma.

\section{Epidemiology and etiology}

The most common causes of hypercalcemia in the United States are primary hyperthyroidism and malignancy. Hypercalcemia occurs in up to $20 \%$ to $30 \%$ of cancer patients at some time during the course of their disease, and predominantly encountered in hospitalization case, whereas primary hyperthyroidism accounts for the majority of cases in outpatient case $[1,2]$

\section{Pathophysiology}

There are our major types of hypercalcemia associated with cancer: humoral hyperclacemia of malignancy, local osteolytic hypercalcemia, calcitriol-secreting lymphoma, and ectopic hyperparathyroidism [1]. Humoral hypercalcemia of malignancy (HHM) is the most common mechanism of hypercalcemia in the cancer patients. Many cancer cells secrete parathyroid hormone-related protein (PTHrP), which binds to the parathyroid receptors in bones and renal tissues, resulting in increased bone resorption and renal tubular reabsorption. This mechanism can be associated with any types of cancer, but it is most commonly associated with squamous-cell cancers (head/neck lung, esophagus, and skin), renal cancer, ovarian or endometrial cancer, breast cancer, and human T-cell leukemia virus-I associated with lymphoma [3]. The diagnosis of humoral hypercalcemia of malignancy can be confirmed by an elevated serum PTH-related protein. However, HHM is distinguished from primary parathyroidism by low level of parathyroid hormone and 1,25-dihydroxyvitamin $\mathrm{D}$ (calcitriol). Local osteolytic Hypercalcemia (LOH), account for about $20 \%$ of the cases of hypercalcemia of malignancy, is associated with extensive bone involvement by metastatic disease leading to high bone resorption and osteolytic lesions [3]. Tumor cells found in the bone marrow secrete stimulatory factors (IL-1 and 6, prostaglandin E2, TNF, PTHrP, and macrophage colony-stimulating factor) enhancing osteoclast activity [3]. Hypercalcemia patients associated with Local osteolytic Hypercalcemia are differentiated from Primary hyperthyroidism and Humoral hypercalcemia of malignancy by normal or slightly elevated PO4 levels, normal level of immunoreactive PTHrP, and presence of bone metastases or bone marrow infiltration [3]. This mechanism is typically associated with breast cancer, multiple myeloma, and lymphoma [1]. The other causes of hypercalcemia of malignancy are calcitriol-mediated hypercalcemia and ectopic PTH secretion. Those types are relatively rare causes of hypercalcemia, account for less than $1 \%$ of cases. All histologic subtypes of lymphoma may produce the active form of vitamin $\mathrm{D}$ (calcitriol) that leads to increase absorption of calcium in intestine [3]. Ectopic hyperparathyroidism is the most rare cause of hypercalcemia in malignancy. It causes hypercalcemia as a result of the ectopic production and secretion of intact parathyroid hormone by neuroendocrine tumor [3].

\section{Symptom overview}

Clinical manifestations of hypercalcemia vary in calcium level in

Correspondence to: Sonia Amin Thomas (Sonia Patel), PharmD, Assistant Professor of Pharmacy Practice, Clinical Oncology Specialist Pharmacist, Philadelphia College of Osteopathic Medicine School of Pharmacy- GA , Campus, North Fulton Hospital, 625 Old Peachtree Road, Suwanee, GA 30024, USA, Tel: 404-751-7414; E-mail: soniapa@pcom.edu

Key words: hypercalcemia, malignancy, cancer, calcium, bisphosphonates, denosumab

Received: Janaury 15, 2015; Accepted: February 02, 2016; Published: February 06, 2016 
blood. Normal range of serum calcium level is 8.5 to $10.5 \mathrm{mg} / \mathrm{dL}$ and normal range of ionized calcium level is 4 to $5.6 \mathrm{mg} / \mathrm{dL}$. The severity of hypercalcemia is classified into three categories based on the level of total serum calcium (Figure 1).

Patients with mild to moderate hypercalcemia, which is total serum calcium between 10.5 and $12 \mathrm{mg} / \mathrm{dL}$ or of ionized calcium between 5.6 to $8 \mathrm{mg} / \mathrm{dL}$, can be asymptomatic [2]. The presenting signs and symptoms of hypercalcemia occur when the serum calcium level rises above those ranges. Patients with a chronic calcium level of 12 to 14 $\mathrm{mg} / \mathrm{dL}$ may tolerate those levels well, whereas sudden development of hypercalcemia in this range or higher may lead to dramatic changes in a patient's mental status. The mnemonic "stones, bones, abdominal moans, and psychic groans" describes the constellation of symptoms and signs of hypercalcemia [2]. The clinical manifestations of hypercalcemia include: Central nervous system effects include lethargy, impaired concentration, fatigue, and muscle weakness; Renal effects include dehydration, polyuria, nocturia, nephrolithiasis resulting from hypercalciuria, nephrogenic diabetic insipidus, and nephrocalcinosis; Gastrointestinal effects include nausea, vomiting, anorexia, weight loss, constipation, abdominal pain, pancreatitis, and PUD; Cardiovascular effects include hypertension, shortened QT interval on electrocardiogram, cardiac arrhythmias, vascular calcification. Other symptoms include bone pain, arthritis, and osteoporosis. [2].

Treatment options (Dose, frequency, titration parameters, time to effect/symptom resolution, expected effects, special or target populations for specific therapies, side effects and their management)

The optimal therapy for hypercalcemia of malignancy is dependent on the severity of hypercalcemia and underlying causes. Hypercalcemia associated with malignancy would be resolved with definitive antitumor therapy of the underlying cancer with chemotherapy [3]. If it is not resolved with proper anticancer therapy, anti-hypercalcemic therapy focusing on targeting the pathophysiologic mechanisms should be considered. It is essential that withholding anti-hypercalcemic therapy may result in life-threatening emergency such as coma and death. Asymptomatic patients with mild hypercalcemia (serum Ca level of 10.5 to $12 \mathrm{mg} / \mathrm{dL}$ ) generally do not require immediate treatment. The general supportive cares for hypercalcemia includes the removal

\begin{tabular}{llll}
\multicolumn{7}{c}{ Total serum calcium level, $\mathrm{mg} / \mathrm{dL}$ ( $\mathrm{mmol} / \mathrm{L})$} \\
$8(2)$ & $10(2.5)$ & $12(3)$ & $14(3.5)$
\end{tabular}

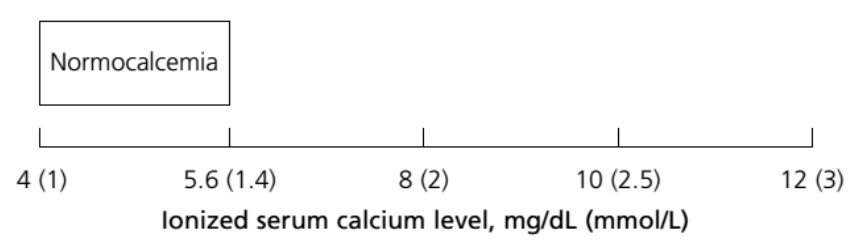

Figure 1. Severity of hypercalcemia by serum total/ionized calcium level [2]. calcium intake from any sources (IV, PO Ca supplements), an increase in oral free water intake, discontinuation of medications causing hypercalcemia (thiazide diuretics, lithium, vitamin D, carbonate therapy), an increase in the weight-bearing ambulation/activities, and discontinuation of sedative drugs analgesics [2]. Symptomatic patient with serum Ca levels greater than $12 \mathrm{mg} / \mathrm{dL}$ or patients with serum Ca levels greater than $14 \mathrm{mg} / \mathrm{dL}$ should be immediately and aggressively treated with anti-hypercalcemic therapy: hydration with saline rehydration followed by loop diuretics, calcitonin, bisphosphonates, and denosumab. For the majority of cancer patients with hypercalcemia have Humoral Hypercalcemia of malignancy (HHM) and Local Osteolytic Hypercalcemia (LOH), intravenous bisphosphonates or subcutaneous/intramuscular calcitonin or subcutaneous denosumab can be used to inhibit osteoclast-mediated bone resorption. Calcitriolmediated hypercalcemia is treated with intravenous glucocorticoid therapy along with limitation of calcium intake to inhibit vitamin D conversion to calcitriol. All pharmacologic therapy for hypercalcemia of malignancy is summarized in Table 1.

\section{Hydration with normal saline followed by low-dose furosemide}

Most patients with hypercalcemia associated with malignancy are dehydrated as a result of renal dysfunction induced by hypercalcemia and by decreased oral fluid intake resulting from nausea and vomiting. Therefore, the cornerstone of initial treatment of hypercalcemia is volume expansion with intravenous normal saline to increase the glomerular filtration rate and renal calcium excretion. Rehydration can be accomplished by IV normal saline at rate of 200 to $500 \mathrm{ml} / \mathrm{hr}$ or 2 to 4 liter per day depending on renal function, the baseline status of dehydration, and the severity of hypercalcemia. Hydration with normal saline should be continued until patients are fully resuscitated, serum calcium level is corrected within the normal range, and the urine output is maintained at $200 \mathrm{ml} / \mathrm{hr}[1,2]$. The hydration state is assessed by measuring fluid intake and output or by central venous pressure monitoring. However, the aggressive hydration can exacerbate heart failure in elderly patients, the use of hydration is limited in patients with congestive heart failure. Once intravascular volume has been restored, low-dose of furosemide (20-40mg IV) every 1 to 4 hours can be used to further lower the serum calcium level and or prevent the development of volume overload from normal saline administration; it block calcium reabsorption in the loop of Henle and increase urine output leading possible increased saline administration, which induces further calcium renal excretion [1].

\section{Bisphosphonates; first-line medications}

Bisphosphonate therapy should be initiated as soon as hypercalcemia is discovered, because it takes two to four days to appear the calcium level lowering effect. The maximum effect generally occurs within four to seven day after initiation of bisphosphonates. About 60 to 90 percent of patients achieve their normal calcium level within four to seven days, and response last for one to three weeks [1]. Two bisphosphonate agents, Pamidronate (Aredia) and Zoledronic acid (Zometa), are approved by the U.S Food and Drug Administration for the treatment of hypercalcemia of malignancy. Bisphosphonates inhibit bone resorption and decrease bone mineralization by disrupting osteoclast activity. Most commonly reported adverse reactions are renal toxicity, flu-like symptoms, injection site reactions, hypocalcemia, hypophosphatemia, fatigue, muscle weakness, and constipation of diarrhea. Co-administration of oral calcium supplement of $500 \mathrm{mg}$ and multiple vitamins containing $400 \mathrm{IU}$ of vitamin D are recommended to 
Table 1. Pharmacologic options for Hypercalcemia associated with cancer

\begin{tabular}{|c|c|c|c|}
\hline Intervention & MOA & Dose & Adverse Effects \\
\hline \multicolumn{4}{|c|}{ Re-Hydration with NS Followed by Loop diuretics } \\
\hline IV Normal saline & Enhance GFR and renal excretion of $\mathrm{Ca}^{2+}$ & $\begin{array}{l}200-500 \mathrm{ml} / \mathrm{hr} \text { or } 2-4 \text { liter } / \text { day for } 1 \text { to } 3 \text { days depending on } \\
\text { the cardiovascular and renal status of patient }\end{array}$ & Volume overload; may exacerbate heart failure \\
\hline Furosemide & Inhibit $\mathrm{Ca}^{2+}$ resorption in the renal tube & 20-40 mg IV; AFTER REHYDATION has been achieved & $\begin{array}{l}\text { Hypokalemia, renal failure, abnormalities of } \\
\text { cardiac conduction }\end{array}$ \\
\hline \multicolumn{4}{|c|}{ First-line medications: Intravenous Bisphosphonate } \\
\hline Pamidronate & \multirow[t]{2}{*}{$\begin{array}{l}\text { Inhibit osteoclast activity; decrease bone } \\
\text { resorption }\end{array}$} & $\begin{array}{l}60-90 \mathrm{mg} \text { IV over } 2 \mathrm{hr} \text { in a solution of } 50-200 \mathrm{ml} \text { of NS or } \\
\text { D5W }\end{array}$ & \multirow{2}{*}{$\begin{array}{l}\text { Nephrotoxicity, flu-like symptoms with fever, } \\
\text { chills, headache }\end{array}$} \\
\hline Zoledronic acid & & $4 \mathrm{mg}$ IV over $15 \mathrm{~min}$ in a solution of $50 \mathrm{ml} \mathrm{NS}$ or D5W & \\
\hline \multicolumn{4}{|c|}{ Second-line medications } \\
\hline Glucocorticoids & Inhibit vitamin $\mathrm{D}$ conversion to calcitriol & $\begin{array}{l}\text { Oral prednisone } 20-40 \mathrm{mg} / \text { day for } 10 \text { days, IV } \\
\text { hydrocortisone } 200 \mathrm{mg} \text { daily for } 3 \text { days or equivalents }\end{array}$ & $\begin{array}{l}\text { Immune suppression, myopathy, } \uparrow \text { glucose in } \\
\text { blood, weight gain, } \uparrow \text { blood pressure }\end{array}$ \\
\hline Calcitonin [8] & 4-8 IU/kg SQ or IM every 12 hour & Inhibit bone resorption & $\begin{array}{l}\text { May rebound } \uparrow \mathrm{Ca}^{2+} \text { after } 24 \text { hours; cause } \\
\text { vomiting, cramps, flushing }\end{array}$ \\
\hline Mithramycin & Inhibit osteoclast activity & $25 \mathrm{mcg} / \mathrm{kg}$ over 4 to 6 hours in NS or D5w solution & Bone marrow suppression, nephron/hepatic toxicity \\
\hline Gallium nitrate [10] & Inhibit osteoclast activity & $\begin{array}{l}\text { IV continuously infusion at } 100-200 \mathrm{mg} / \mathrm{m} 2 \text { over } 24 \text { hours } \\
\text { for five days }\end{array}$ & Bone marrow suppression, nephrotoxicity \\
\hline
\end{tabular}

Table 2. First-line medication for hypercalcemia associated with cancer.

\begin{tabular}{|c|c|c|c|c|c|}
\hline & Dose/Administration & Onset of action & Renal dose adjustment & Monitoring parameters & Note \\
\hline $\begin{array}{l}\text { Pamidronate } \\
\text { (Aredia) }[6,11]\end{array}$ & $\begin{array}{l}\text { - Route: Intravenous } \\
\text { - Available in } 30 \mathrm{mg}, 60 \mathrm{mg} \text {, or } \\
90 \mathrm{mg} \text { vials for IV administration; } \\
\text { reconstituted with } 10 \mathrm{ml} \text { of sterile water } \\
\text { or D5W } \\
\text { - Moderate hypercalcemia: } 60 \text { to } 90 \mathrm{mg} \\
\text { as single dose IV infusion over } 4 \text { hours } \\
\text { once every } 3 \text { to } 4 \text { weeks } \\
\text { - Severe hypercalcemia: } 90 \mathrm{mg} \text { as single } \\
\text { dose IV infusion over } 24 \text { hour } \\
\text { - Retreatment: Recommended that } \\
\text { a minimum of } 7 \text { days elapse before } \\
\text { retreatment to allow for full response to } \\
\text { the initial dose. }\end{array}$ & $\begin{array}{l}\text { - initial Ca lowering } \\
\text { effect: } 2-4 \text { days } \\
\text { - maximum effects: } \\
\text { about } 4 \text { to } 7 \text { days } \\
\text { after initiation of } \\
\text { therapy }\end{array}$ & $\begin{array}{l}\text { - severe renal impairment }(\mathrm{SCr} \\
>3 \mathrm{mg} / \mathrm{ml} \text { or } \mathrm{CrCr}<30 \mathrm{ml} / \\
\text { minutes): reduced initial dose } \\
\text { should be considered. } \\
\text {-Increase of } \mathrm{SCr} \geq 0.5 \mathrm{mg} / \mathrm{dL} \\
\text { in patients with normal baseline } \\
(\mathrm{SCr}<1.4 \mathrm{mg} / \mathrm{dL}) \\
\text { - Increase of } \mathrm{SCr} \geq 1 \mathrm{mg} / \mathrm{dL} \text { in } \\
\text { patients with abnormal baseline } \\
(\mathrm{SCr} \geq 1.4 \mathrm{mg} / \mathrm{dL})\end{array}$ & $\begin{array}{l}\mathrm{SCr} \text {, electrolytes (Ca, PO4, } \\
\mathrm{Mg}, \mathrm{K}), \mathrm{CBC} \text {, hypocalcemia } \\
\text { symptoms for at least } 2 \\
\text { weeks after therapy, dental } \\
\text { exam prior to therapy, } \\
\text { all cancer patients (pre- } \\
\text { existing anemia, leukopenia, } \\
\text { thromobocytopenia) should } \\
\text { be monitored during the first } \\
2 \text { weeks of treatment; urine } \\
\text { albumin every } 3 \text { to } 6 \text { months } \\
\text { in multiple myeloma patients. }\end{array}$ & $\begin{array}{l}\text { Contraindication: hypersensitivity } \\
\text { to pamidronate or other } \\
\text { bisphosphonates. } \\
\text { Pregnancy D: } \\
\text { there are no adequate and well- } \\
\text { controlled studies in pregnancy. } \\
\text { However, adverse events were } \\
\text { observed in animal reproduction } \\
\text { studies. It is not known if } \\
\text { pamidronate cross the placenta, but } \\
\text { fetal exposure is expected. } \\
\text { Breast-feeding: } \\
\text { Not recommend }\end{array}$ \\
\hline $\begin{array}{l}\text { Zoledronic acid } \\
\text { (Zometa) }[7,12]\end{array}$ & $\begin{array}{l}\text { - Route: Intravenous } \\
\text { - Available in } 4 \mathrm{mg} / 5 \mathrm{ml} \text { and } 5 \mathrm{mg} / 100 \mathrm{ml} \\
\text { vials for IV administration } \\
\text { - Hypercalcemia of malignancy } \\
\text { (corrected } \mathrm{Ca} \geq 12 \mathrm{mg} / \mathrm{dL}): 4 \mathrm{mg} \mathrm{IV} \\
\text { given as a single dose over } 15 \mathrm{minutes} \text {. } \\
\\
\text { - Retreatment: wait at least } 7 \text { days } \\
\text { before re-treatment; } 4 \mathrm{mg} \text { as retreatment }\end{array}$ & $\begin{array}{l}\text { - Similar to } \\
\text { pamidronate. }\end{array}$ & $\begin{array}{l}\text { - Severe renal impairment (SCr } \\
>4.5 \mathrm{mg} / \mathrm{dL} \text { ): evaluate risk Vs. } \\
\text { benefit } \\
\text { - } \mathrm{CrCL}>60 \mathrm{ml} / \mathrm{min}: 4 \mathrm{mg} \text {; no } \\
\text { dosage adjustment is required. } \\
\text { - CrCL 50-60: reduced dose } \\
\text { to } 3.5 \mathrm{mg} \\
\text { - CrCL 40-49: reduced dose } \\
\text { to } 3.3 \mathrm{mg} \\
\text { - CrCL 30-39: reduced dose } \\
\text { to } 3 \mathrm{mg} \\
\text { - CrCL < 30: not recommended }\end{array}$ & Same as Pamidronate & $\begin{array}{l}\text { Contraindication: hypersensitivity } \\
\text { to Zoledronic acid or other } \\
\text { bisphosphonates. } \\
\text { Pregnancy D: } \\
\text { : there are no adequate and well- } \\
\text { controlled studies in pregnancy. } \\
\text { Theoretically, there may be a risk } \\
\text { of fetal harm when pregnancy } \\
\text { follows the completion of therapy } \\
\text { Breast-feeding: } \\
\text { Not recommend }\end{array}$ \\
\hline $\begin{array}{l}\text { Denosumab } \\
\text { (Xgeva) [9] }\end{array}$ & $\begin{array}{l}\text { - Subqutaneous } \\
\text { - Available in } 120 \mathrm{mg} / 1.7 \mathrm{~mL}(70 \mathrm{mg} / \\
\text { mL) solution in a single-use vial } \\
\text { - Treatment of hyperkalemia of } \\
\text { malignancy: } 120 \mathrm{mg} \text { subcutaneous } \\
\text { every } 4 \text { week; give an additional } 120 \\
\text { mg on days } 8 \text { and } 15 \text { during the first } \\
\text { month. }\end{array}$ & $\begin{array}{l}\text { - About } 85 \% \text { patients } \\
\text { within } 3 \text { days; } \\
\text { maximal reductions } \\
\text { observed within } 1 \\
\text { months } \\
\text { - Time to initial } \\
\text { response: median } \\
\text { time } 9 \text { days } \\
\text { - Time to complete } \\
\text { response: median } \\
\text { time } 23 \text { days }\end{array}$ & $\begin{array}{l}\text { No hepatic/Renal dose } \\
\text { adjustment }\end{array}$ & $\begin{array}{l}\mathrm{SCr} \text {, serum electrolytes } \\
(\mathrm{Ca}, \mathrm{PO} 4, \mathrm{Mg}), \mathrm{s} / \text { sx of } \\
\text { hypocalcemia, infection, } \\
\text { injection site reactions, dental } \\
\text { exam }\end{array}$ & $\begin{array}{l}\text { Limitation: } \\
\text { Denosumab is not indicated for } \\
\text { the prevention of skeletal-related } \\
\text { events in patients with multiple } \\
\text { myeloma } \\
\text { Contraindication: } \\
\begin{array}{l}\text { Hypersensitivity to Denosumab; } \\
\text { Pre-existing Hypocalcemia }\end{array} \\
\text { Pregnancy D: } \\
\text { Adverse events were observed in } \\
\text { animal reproduction studies. } \\
\text { Breast-feeding: } \\
\text { Not recommend }\end{array}$ \\
\hline
\end{tabular}


prevent hypercalcemia [4-7].

\section{Denosumab (Xgeva); Human monoclonal antibody; First-line medication}

Denosumab, a full human IgG2 monoclonal antibody against RANKL, can be used for the management of hypercalcemia of malignancy in patients with persistent hypercalcemia despite bisphosphonates. Denosumab binds to RANKL (soluble protein essential for the formation, function, and survival of osteoclast), and inhibit osteoclast activity resulting in decreased skeletal-related events and tumor-induced bone destruction [8,9]. Unlike bisphosphonates, denosumab is not cleared by kidney, and there is no restriction of use in patients with chronic renal impairment whom bisphosphonates used with caution or contraindicated [4]. In a clinical trial, 33 patients with hypercalcemia of malignancy with persistently elevated serum calcium levels after treatment with zoledronic acid were treated with denosumab $120 \mathrm{mg}$ subcutaneously weekly for 4 weeks and monthly thereafter [5]. In case reports of hypercalcemia patients with multiple myeloma and severe renal impairment, denosumab decreased serum calcium level within 2 to 4 days, and in one case was associated with improvement in renal function [9] (Table 2).

\section{Second-line medications: Glucocorticoid, mithramycin, calcitonin, gallium nitrate}

Glucocorticoids can be used in treatment option for hypercalcemia patients with excessive administration of vitamin $\mathrm{D}$ or the endogenous overproduction of calcitriol secondary to lymphoma [1]. In those condition, glucocorticoids such as oral prednisone $20-40 \mathrm{mg} /$ day for 10 days, IV hydrocortisone $200 \mathrm{mg}$ daily for 3 days or equivalents [1,3].

Calcitonin can be used as alternative to saline hydration therapy for patients with severe chronic heart failure or moderate to severe renal dysfunction. The initiation of subcutaneous calcitonin may result in a more rapid reduction in serum calcium levels than other agents (maximal response occurs within 12 to 24 hours), but the effect and extent of serum calcium level reduction are often erratic [1].

Mitramycin (plicamycin), a potent cytotoxic antibiotic, reduce serum calcium level by inhibiting osteoclast-mediated bone resorption. Mithramycin is administered via IV infusion at $25 \mathrm{mcg} / \mathrm{kg}$ over 4 to 6 hours in normal saline or D5w solution [1]. This therapy can be repeated daily for 3 to 4 days, and the serum calcium lowering effect begin to fall within 12 hours of initiation. However, mithramycin is not commonly recommended in hypercalcemia associated with malignancy due to dose-related adverse effects including nausea, vomiting, stomatitis, thrombocytopenia, and renal and hepatotoxicity.

Gallium nitrate is approved for treatment in hypercalcemia of malignancy. This agent decrease serum calcium level by inhibiting osteoclast activity. It is given via IV continuously infusion at 100-200 $\mathrm{mg} / \mathrm{m}^{2}$ over 24 hours for five days [1]. The common adverse events are renal dysfunction, hypocalcemia, hypophosphatemia, decreased serum bicarbonates, and hypotension. Since Administration of Gallium nitrate required continuous IV infusion over 24 hours, it is not commonly used [10-12].

\section{Summery}

Hypercalcemia of malignancy is a one of the most common complication of advanced breast cancer, squamous cell cancers, and multiple myeloma. Those types of cancer are highly associated with bone metastases or skeletal involvement. Therefore, hypercalcemia develops more quickly than other causes such as parathyroid hormonerelated, medications-related, vitamin D-related, and genetic disorders [2]. The development of this cancer-associated with complication is associated with a poor prognosis, and severe/acute hypercalcemia leads to severe mental impairment, renal failure, and life-threatening medical emergency. Clinical manifestations of hypercalcemia vary in the level of calcium in the blood, and the severity of hypercalcemia is classified into three categories based on the serum calcium level: mild, moderate, hypercalcemic crisis [2]. There are four mechanisms of hypercalcemia in the cancer patient: humoral hyperclacemia of malignancy, local osteolytic hypercalcemia, calcitriol-secreting lymphoma, and ectopic hyperparathyroidism $[1,3]$. Humoral hyperclacemia of malignancy and local osteolytic hypercalcemia are most common causes of hypercalcemia of malignancy, and the others are relatively rare causes of hypercalcemia, which account for less than $1 \%$ of cases. For the clinical intervention in the management of hypercalcemia, aggressive hydration with normal saline and intravenous bisphosphonates are first-line pharmacological options. Since most patients with hypercalcemia are dehydrated as a result of renal dysfunction induced by hypercalcemia or by decreased in oral fluid intake from nausea/ vomiting, hydration with normal saline should be initiated to increase the glomerular filtration rate and renal calcium excretion. In addition, volume expansion with normal saline dilutes calcium concentration in the blood, and inhibits calcium reabsorption in the proximal nephron; saline act as calciuretic [1]. After rehydration has been achieved, Loop diuretic, low-dose of furosemide can be used to prevent volume overload and to induce further renal calcium excretion. Intravenous bisphosphonates and subcutaneous denosumab can be used for severe hypercalcemia associated with cancer; those agents inhibit osteoclast activity and decrease bone resorption. Bisphosphonate agents, pamidronate and zoledronic acid, are not metabolized and are exclusively eliminated by renal excretion [6,7]. Therefore, dose of those agents are should be adjusted by patient's renal function, and are contraindicated in patients with severe renal impairment. Denosumab is also first-line option for hypercalcemia associated with malignancy, but it is not commonly used as first-line due to high cost; its generic version is not available in the United States and price is much expensive than generic version of bisphosphonates. Therefore, denosumab can be used as alternative to bisphosphonates for patients with severe renal impairment. There are several agents could be used as second-line option when bisphosphonates are ineffective or contraindicated. Glucocorticoid is not commonly used, but it is effective in hypercalcemia-induced by endogenous overproduction of calcitriol or excessive ingestion of vitamin D. Calcitonin is safe and nontoxic, and its serum calcium lowering effect is much faster than other agents. However, the efficacy of calcitonin is often erratic, and the duration of calcium lowering effect is relatively short [2]. Mithramycin is not commonly used in hypercalcemia of malignancy due to its severe adverse effects. Finally, gallium nitrate is also approved for treatment, but the need of continuous IV infusion over 24 hours for 5 days limits its use in hypercalcemia of malignancy [1].

\section{References}

1. Andrew FS (2005) Hypercalcemia Associated with Cancer. N Engl J Med 352: 373-379.

2. Carroll MF, Schade DS (2003) A practical approach to hypercalcemia. Am Fam Physician 67: 1959-1966. [Crossref]

3. Mimi IH (2012) Hypercalcemia of Malignancy: Current \& Future Directions. ENDO perspectives. 5 
4. Dietzek A, Connelly K, Cotugno M, Bartel S, McDonnell AM (2015) Denosumab in hypercalcemia of malignancy: a case series. J Oncol Pharm Pract 21: 143-147. [Crossref]

5. Adhikaree J, Newby Y, Sundar S (2014) Denosumab should be the treatment of choice for bisphosphonate refractory hypercalcaemia of malignancy. BMJ Case Rep. [Crossref]

6. (2007) Pamidronate [package insert]. East Hanover, NJ: Novartis Pharmaceutical Corporation.

7. (2015) Zoledronic Acid [package insert]. East Hanover, NJ: Novartis Pharmaceutical Corporation.
8. (2015) Miacalcin [package insert]. East Hanover, NJ: Novartis Pharmaceutical Corporation.

9. (2015) Denosumab [package insert]. Thousand Oaks, CA: Amgen Inc.

10. Lexi-Drugs. Lexicomp [Internet]. Hudson OH: Wolters Kluwer Health, Inc. 19782015. Gallium Nitrate; [cited 2015 Aug 21]. Available from: http://online.lexi.com

11. Lexi-Drugs. Lexicomp [Internet]. Hudson OH: Wolters Kluwer Health, Inc. 19782015. Pamidronate; [cited 2015 Aug 21]. Available from: http://online.lexi.com

12. Lexi-Drugs. Lexicomp [Internet]. Hudson OH: Wolters Kluwer Health, Inc. 19782015. Denosumab; [cited 2015 Aug 21]. Available from: http://online.lexi.com

Copyright: (C) 2016 Thomas SA. This is an open-access article distributed under the terms of the Creative Commons Attribution License, which permits unrestricted use, distribution, and reproduction in any medium, provided the original author and source are credited. 